\title{
A Rare Hand Pain Cause, Schwannoma with Median Nerve Localisation
}

\author{
Nadir Bir El Ağrısı Sebebi, Median Sinir Schwannomu \\ Mehmet ALBAYRAK
}

Özel Tekirdağ Yaşam Hospital, Clinic of Orthopedics and Traumatology, Tekirdağ, Turkey

\begin{abstract}
Schwannoma is a firm, properly limited, encapsulated, and slow-growing benign tumor of nerve sheaths. It can be seen at all ages, most commonly between the ages of 20 and 50 years and the ratio of female to male is $2: 1$. It is most commonly seen in the head and neck, but $20 \%$ of Schwannomas arise from the peripheral nerves. Peripheral nerve Schwannomas can easily be misdiagnosed as nerve entrapment syndromes because their symptoms overlap most of the times. Symptoms occur by pressing on the mass or on the surrounding tissues. There is no medical treatment of Schwannomas, but the treatment is total excision of the mass. In this case report, a 64-year-old male patient with a Schwannoma of the median nerve in the left forearm, who was misdiagnosed and misoperated as carpal tunnel syndrome, is reported.
\end{abstract}

Keywords: Schwannoma, median nerve, pain

\section{ÖZ}

Schwannom, sinir kılıflarının sert, iyi sınırlı, kapsüllü ve yavaş büyüyen iyi huylu bir tümörüdür. Her yaşta görülebilir, en sık 20-50 yaş arasında görülür ve kadın/erkek oranı 2:1'dir. En sık baş ve boyunda görülür, ancak Schwannom'ların \%20'si periferik sinirlerden kaynaklanır. Periferik sinir Schwannom'ları, semptomları çoğu zaman sinir tuzaklanmaları ile örtüştüğü için kolayca yanlış teşhis edilebilirler. Semptomlar kitleye veya çevre dokulara basılarak ortaya çıkar, Schwannom'ların medikal tedavisi yoktur, tedavi kitlenin tamamen çıkarılmasıdır. Bu olgu sunumunda, karpal tünel sendromu olarak yanlış tanı konulan ve yanlışıkla ameliyat edilen, sol ön kolda median sinir Schwannom'u olan 64 yaşında bir erkek hasta bildirilmiştir.

Anahtar Kelimeler: Schwannom, median sinir, ağrı

\section{INTRODUCTION}

Schwannoma is a firm, properly limited, encapsulated, and slow-growing benign tumor of peripheral nerve sheath 1 . It can be seen at all ages, mostly between the ages of 20 and 50 years, and the ratio of female to male is $2: 1^{2}$. Although Schwannomas arise from the peripheral nerves by $20 \%$, they are mostly in the head and neck ${ }^{1-4}$. Peripheral nerve Schwannomas symptoms may mimic nerve entrapment syndrome symptoms, so they should be differentiated carefully in the differential diagnosis.
No medical treatment of Schwannomas exists, thereby it is completely surgical ${ }^{5}$.

\section{CASE REPORT}

A 64-year-old male patient was seen with left hand pain and numbness. The patient reported no systemic complaints and stated that he had had an operation for a carpal tunnel syndrome in another institution with the same complaints a year ago; however, he did not experience any improvement.

Address for Correspondence: Mehmet ALBAYRAK MD, Özel Tekirdağ Yaşam Hospital, Clinic of Orthopedics and Traumatology, Tekirdağ, Turkey Phone: +90 5336605013 E-mail: doktorm.albayrak@gmail.com ORCID ID: orcid.org/0000-0002-4074-7024

Received: 30.03.2021 Accepted: 14.08.2021

๑Copyright 2021 by the Tekirdağ Namık Kemal University Faculty of Medicine / Namık Kemal Medical Journal published by Galenos Publishing House. 
On physical examination, a well-healed surgical scar consistent with an open carpal tunnel release on the palmar side of the left hand was observed. The hand and wrist were normal with Phalen, Tinnel Wartenberg, and Froment tests being negative and there were no sensory impairments. However, during the palpation of the forearm, an area causing severe pain on the volar side and in the thumb of the hand was detected. The Tinel test in the same area was also significantly positive. The patient's visual analogue scale (VAS) score was $70 \mathrm{~mm}$.

$\mathrm{X}$ rays, neurophysiological tests, and magnetic resonance imaging (MRI) of the hand, and arterial and venous doppler ultrasonography in the left upper extremity performed because of the on-going postoperative complaints were normal. However, MRI of the forearm revealed a soft tissue tumor at the volar aspect between the flexor muscles, and in the exact localization corresponding to the median nerve trace. The tumor was well-circumscribed, with the dimensions
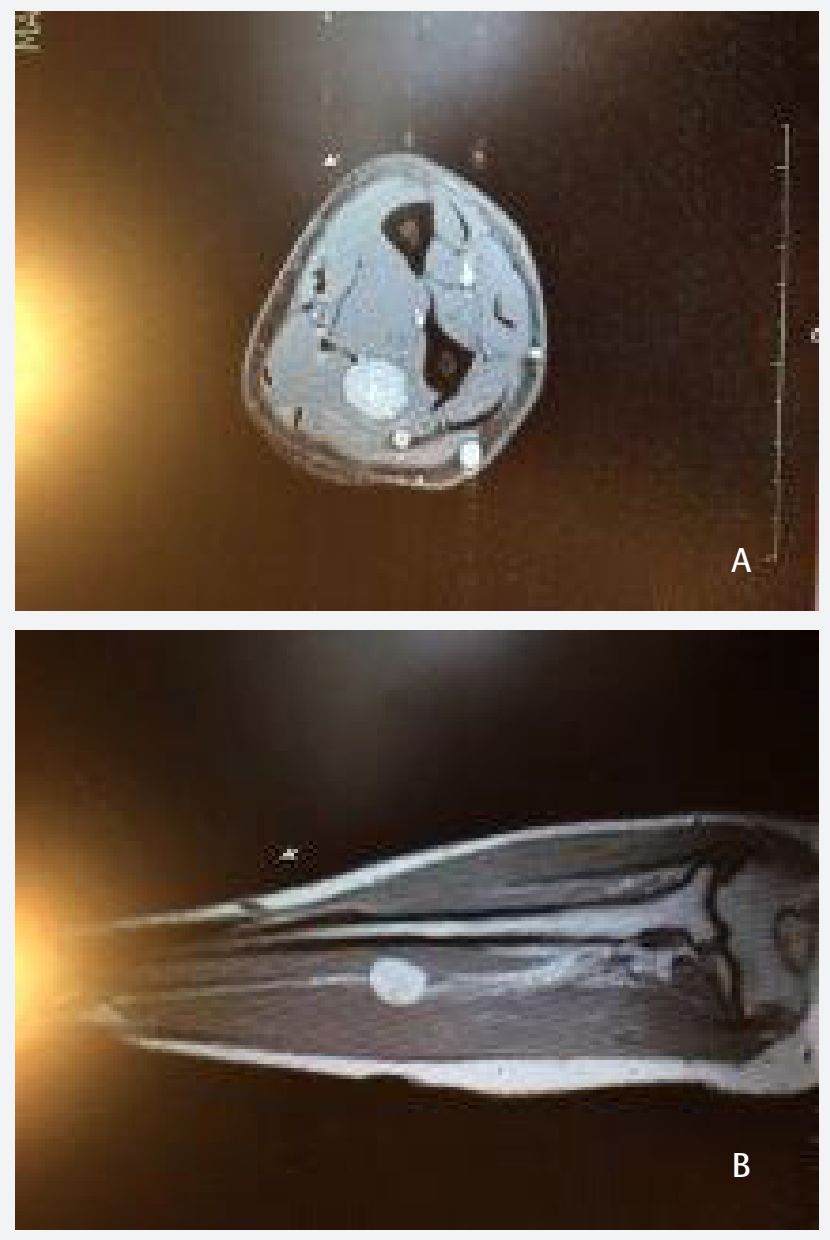

Figure 1. A) Magnetic resonance imaging revealed a 23×16 $\mathrm{mm}$ mass located in median nerve intermediate signal on T2-weighted axial images. B) Magnetic resonance imaging revealed a $23 \times 16 \mathrm{~mm}$ mass located in median nerve intermediate signal on T1-weighted saggital images of $23 \times 16 \mathrm{~mm}$, isointense in T1-weighted and hyperintense in T2-weighted sequences, showing a homogeneous contrast enhancement after gadolinum contrast material injection, and was compatible with a Schwannoma (Figures 1A, 1B).

After having written informed consent from the patient, he was operated under general anesthesia with pneumatic tourniquet control. By opening nerve sheath, the tumor was totally removed without any compromise to the nerve, leaving the nerve intact. The mass was well-circumscribed and easily distinguishable from the surrounding tissues. It was revealed that the mass had originated from the median nerve after separation from the vascular pack and surrounding tissues. It appeared to be mediumly firm, yellowish, well-circumscribed, and encapsulated. (Figure 2A, 2B, 2C, 2D).

The postoperative neurological examination was normal. The patient was discharged with full recovery on the first postoperative day. Histological result was Schwannoma with abundant spindle-cell Antoni $A$ tissue and small-cell thickwalled veined Antoni B tissue. Immunohistochemical S-100 staining supported the diagnosis. The patient reported that all his complaints were relieved immediately. At the end of the second week, he was completely asymptomatic and returned to his daily activities. After two years of follow-up, physical examination was completely normal, and VAS score was $0 \mathrm{~mm}$.

\section{DISCUSSION}

Peripheral nerve sheath tumors are benign, they originate from Schwann cells and were first described by Verocay in 19081. Although it can be seen at all ages, it is most common between the ages of 20 and 50 years, and the ratio of female to male is $2: 1^{6} .20 \%$ of all Schwannomas are located in the peripheral nerves ${ }^{2}$. Schwannomas of the median nerve make up 0.1-0.3\% of all hand tumors ${ }^{7,8}$.

Schwannomas rarely show malignant transformation and are encapsulated and well-circumscribed tumors. It shows a biphasic pattern histopathologically $y^{3,4}$.

The Antoni A pattern consists of long nucleated, sequential spindle-shaped cells forming fascicles and strips. The Antoni B pattern consists of hypocellular areas that contain a small number of spindle cells with a weak myxoid matrix. Oval acellular areas surrounded by parallel nuclei known as Verocay bodies can be seen. Histopathologic examination of our case also showed Antoni A and Antoni B regions, composed of nucleated, sequential spindle-shaped cells forming fascicles and strips which are compatible with Schwannoma.

MRI is an appropriate choice of imaging thecnique for the diagnosis and the treatment plan. In T1- and T2-weighted images, high signal intensity is evident and there is a heterogeneous, sharp-edge contrast uptake. It shows the 

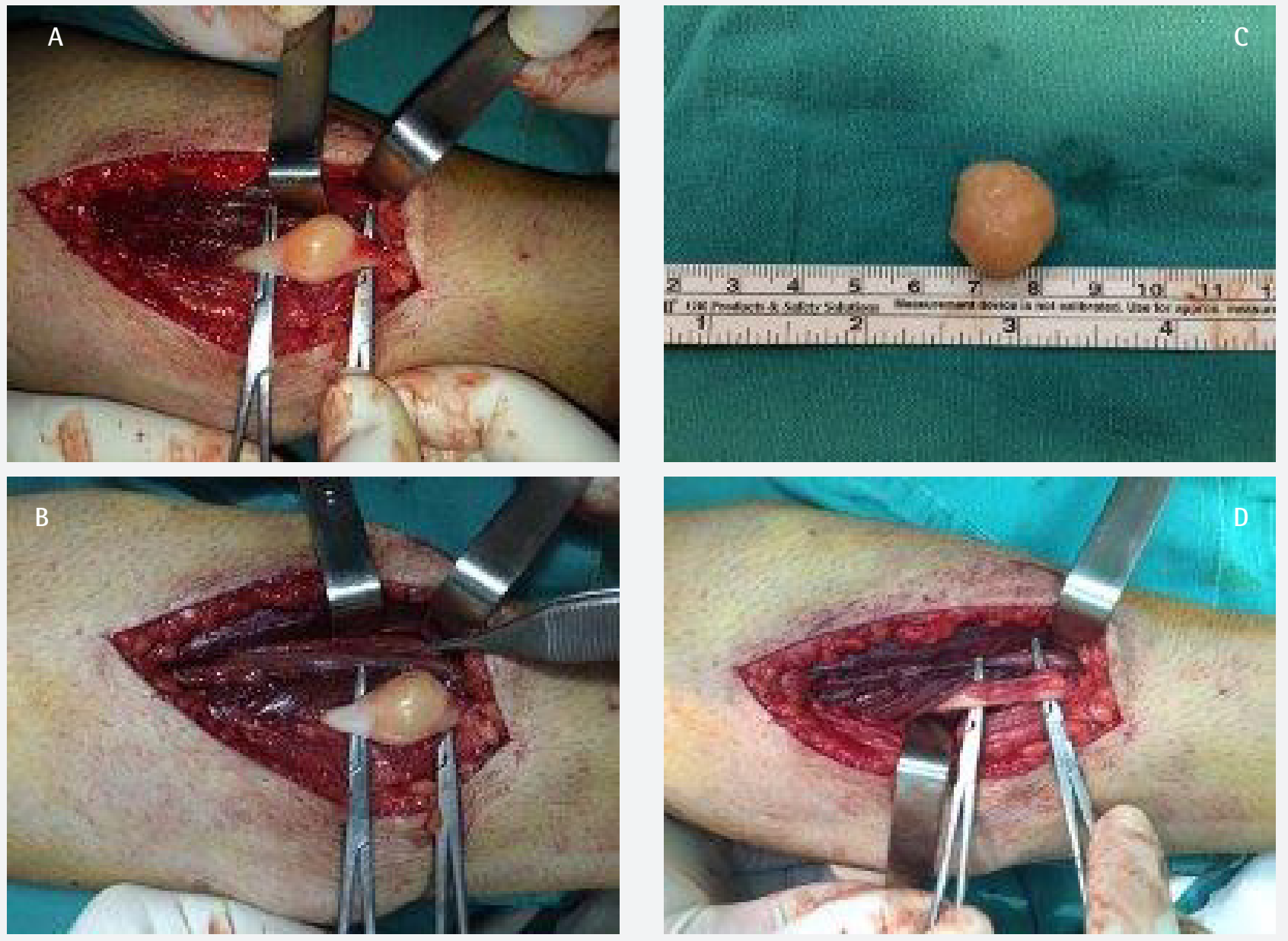

Figure 2. A) Intraoperative view of the lesion showing that the mass at the forearm was originated from the median nerve. B) Intraoperative view of the lesion showing that the mass at the forearm was originated from the median nerve. C) Intraoperative photograph showing dissection of tumour. D) Median nerve after the lesion was removed

anatomical localization of the lesion and its relation to surrounding structures. Also ultrasonography can help to differentiate a solid or cystic nature of the mass.

In the differential diagnosis of these tumors, a fine needle aspiration biopsy can reveal neurogenic source of the tumor ${ }^{3,4}$. Despite all these methods, the diagnosis of these tumors can usually be made after surgery ${ }^{1,5}$.

The gold standard in the treatment is the complete excision of the tumor, preserving the nerve structure from which the tumor originated. In incomplete resections, 10\% recurrence is reported ${ }^{1-5}$. In our case, the tumor was removed totally from the nerve by blunt dissection after dissection from the vesselnerve pack.

\section{CONCLUSION}

Consequently, peripheral Schwannoma is a rarely seen benign tumor. The diagnosis is difficult before surgery. Schwannoma of the median nerve, a condition in which the findings can overlap one-to-one with carpal tunnel syndrome, should be considered in the differential diagnosis of atypical and lingering pain in the upper extremities, and the clinician should be careful not to misdiagnose it and perform unnecessary surgical interventions.

\section{Ethics}

Informed Consent: Consent form was filled out by a participant.

Peer-review: Externally peer-reviewed.

Financial Disclosure: The author declared that this study received no financial support.

\section{References}

1. Padua L, Pazzaglia C, Insola A, Aprile I, Caliandro P, Rampoldi M, et al. Schwannoma of the median nerve (even outside the wrist) may mimic carpal tunnel syndrome. Neurol Sci. 2006;26:430-4.

2. Mersa $B$, Özçelik IB, Yeşiloğlu N. Isolated intraneural schwannoma of the median nerve. J Hand Surg Eur Vol. 2014;39:209-10. 
3. Mankin HJ, Mankin KP. Schwannoma: a rare benign tumor of soft tissues. Musculoskelet Surg. 2014;98:95-9.

4. Eroglu U, Yakar F, Zaimoglu M, Ozgural O, Kahilogulları G. Median nerve schwannoma. ANZ J Surg. 2019;89:1158-9.

5. Aslam N, Kerr G. Multiple schwannomas of the median nerve: a case report and literature review. Hand Surg. 2003;8:249-52.

6. Padasali PS, Shankaregowda VS, Kshirsagar SD. Median nerve schwannoma: A case and review of literature. Asian J Neurosurg. 2015;10:212-5.
7. Albert P, Patel J, Badawy K, Weissinger W, Brenner M, Bourhill I, et al. Peripheral Nerve Schwannoma: A Review of Varying Clinical Presentations and Imaging Findings. J Foot Ankle Surg. 2017;56:632-7.

8. Kütahya H, Güleç A, Güzel Y, Kacira B, Toker S. Schwannoma of the median nerve at the wrist and palmar regions of the hand: a rare case report. Case Rep Orthop. 2013;2013:950106. 